\title{
Factors influencing access to agricultural knowledge: The case of smallholder rice farmers in the Kilombero district of Tanzania
}

\begin{tabular}{|c|c|}
\hline \multicolumn{2}{|c|}{$\begin{array}{l}\text { Authors: } \\
\text { Wulystan P. Mtega }{ }^{1} \\
\text { Mpho Ngoepe }^{2} \\
\text { Luyanda Dube }^{2}\end{array}$} \\
\hline \multicolumn{2}{|c|}{$\begin{array}{l}\text { Affiliations: } \\
{ }^{1} \text { Sokoine University of } \\
\text { Agriculture, Morogoro, } \\
\text { Tanzania }\end{array}$} \\
\hline \multicolumn{2}{|c|}{$\begin{array}{l}{ }^{2} \text { Department of Information } \\
\text { Sciences, University of South } \\
\text { Africa, South Africa }\end{array}$} \\
\hline \multicolumn{2}{|c|}{$\begin{array}{l}\text { Corresponding author: } \\
\text { Mpho Ngoepe, } \\
\text { ngoepms@unisa.ac.za }\end{array}$} \\
\hline \multicolumn{2}{|c|}{$\begin{array}{l}\text { Dates: } \\
\text { Received: } 31 \text { Mar. } 2015 \\
\text { Accepted: } 31 \text { Jan. } 2016 \\
\text { Published: } 27 \text { May } 2016\end{array}$} \\
\hline \multicolumn{2}{|c|}{$\begin{array}{l}\text { How to cite this article: } \\
\text { Mtega, P., Ngoepe, M. \& } \\
\text { Dube, L., 2016, 'Factors } \\
\text { influencing access to } \\
\text { agricultural knowledge: the } \\
\text { case of smallholder rice } \\
\text { farmers in the Kilombero } \\
\text { district of Tanzania', South } \\
\text { African Journal of } \\
\text { Information Management } \\
\text { 18(1), a679. http://dx.doi. } \\
\text { org/10.4102/sajim.v18i1.679 }\end{array}$} \\
\hline \multicolumn{2}{|c|}{$\begin{array}{l}\text { Copyright: } \\
\text { (C) 2016. The Authors } \\
\text { Licensee: AOSIS. This } \\
\text { is licensed under the } \\
\text { Creative Commons } \\
\text { Attribution License. }\end{array}$} \\
\hline \multicolumn{2}{|l|}{ Read online: } \\
\hline 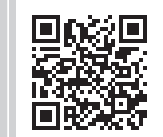 & $\begin{array}{l}\text { Scan this QR } \\
\text { code with your } \\
\text { smart phone or } \\
\text { mobile device } \\
\text { to read online. }\end{array}$ \\
\hline
\end{tabular}

Background: Access to agricultural knowledge is important in transforming livelihoods of those relying on agriculture for a living and in enhancing food security. This access to agricultural knowledge is influenced by infrastructure needed for information dissemination. However, information infrastructure is not uniformly distributed within and between countries. It is because of this that some of the farming communities are information rich while others are information poor. In Tanzania, the agricultural sector is characterised by poor research-extension-farmers linkage and inaccessibility of agricultural knowledge at farm level

Objective: The study investigated the factors influencing access to agricultural knowledge among smallholder rice farmers in the Kilombero district of Tanzania. Specifically, the study identified categories of agricultural knowledge needed by farmers, determined how farmers access agricultural knowledge, and assessed the factors limiting the accessibility of agricultural knowledge among rice farmers in the Kilombero district.

Method: Quantitative data were collected via semi-structured questionnaires administered face-to-face with rice farmers, community leaders, and agricultural agents in four villages at the Kilombero district of the Morogoro region in Tanzania.

Results: The key finding indicates that farmers accessed and used agricultural knowledge in undertaking agricultural activities. It was further revealed that the level of acquisition of agricultural knowledge increased with an increase in age. Farmers needed agricultural knowledge on land preparation, seed selection, and rice planting, while few acquired knowledge on agricultural markets. Among the agricultural knowledge sources used, demonstration plots and agricultural extension agents were found to be used by the majority of the farmers. It was also found that a limited number of demonstration plots, late delivery of information services, a limited number of agricultural extension agents, and poor information and communication technologies infrastructure hindered access to agricultural knowledge among rice farmers in the district.

Conclusion: A strong public-private partnership is needed to enhance access to agricultural knowledge in rural areas. In this regard, the government should set up policies and strategies that motivate private sector investment and involvement in provision of agricultural knowledge in rural areas. The private sector should extend their agricultural-related activities to most rural areas so that more people can have access to agricultural knowledge.

\section{Introduction}

Access to agricultural knowledge is important in transforming livelihoods of those relying on agriculture for a living and in enhancing food security (Lwoga 2011). Access to agricultural knowledge is associated with acquiring skills and techniques for improving farming practices, sustaining the environment, and optimising production within a given farm size. For this to take place, a strong link between agricultural research and farmers is required. Agricultural research institutions come up with new technologies and developments which must reach farmers' farms and homes through effective extension and mass media channels, so that they can adopt new technologies and put them into use (Nazari, Bin \& Hassan 2011). If agricultural technologies and developments do not reach farmers, transforming agriculture and farmers' livelihoods remains impossible. Thus, access to agricultural knowledge is a factor for change and progress in the agricultural sector.

Information is linked to knowledge through the data-information-knowledge hierarchy (Frické 2009) and knowledge is filtered from information. Therefore, access to agricultural knowledge is influenced by the information infrastructure needed for information dissemination. 
The information infrastructure is composed of information and communication systems that process and transport data inside and outside national boundaries (Bowker et al. 2010). The information infrastructure is not uniformly distributed within and between countries. It is because of this that some of the farming communities are knowledge rich while others are knowledge poor. According to Kagan (1999), knowledge rich and knowledge poor are described by the gap between the elite and the disadvantaged within countries, and the accessibility versus the inaccessibility to knowledge among people. Because knowledge is a factor for change, progress, and development, those with better access to knowledge are more likely to be better off compared to those who do not.

Access to agricultural knowledge among farmers in most developing countries has been a challenge for many years (Eenhoorn \& Becx 2009). Despite the contribution of the agricultural sector in Tanzania, scholars (Lwoga, Ngulube \& Stilwell 2011) found that limited access to agricultural knowledge has been mentioned as one of the factors limiting agricultural productivity in Tanzania (Lwoga et al. 2011). With climate change the need for agricultural knowledge has become more urgent as agricultural researchers have been working hard to adapt and mitigate the impacts. In Tanzania, Lema and Majule (2009) found that climate change has brought about reduced productivity in Tanzania. To mitigate climate change impacts, farmers need to rely on a rapidly expanding base of biological and agronomic knowledge that is often specific to certain agro-ecosystems, regions, soil types, and slopes (Tilman et al. 2002). According to Lobell and Gourdji (2012), climate change has affected crop productivity because rains have been reduced and drought periods prolonged. This has made it important for agricultural research institutions to come up with new technologies and developments to combat the impacts. In order to limit the impacts of climate change, making the right decisions at farm level in terms of input-use efficiency, human health, and resource protection is becoming an increasingly knowledgeintensive task (Tilman et al. 2002).

For enhancing access to agricultural knowledge, agricultural extension agents from the public and private sector, access to radio and TV networks, and print resources are important (Shetto 2008). In Tanzania, both governmental and nongovernmental organisations are involved in the provision of agricultural knowledge (Rutatora \& Mattee 2001). According to Lema and Kapange (2006), agricultural knowledge has been shared through farmers' associations and groups. Moreover, as agro-dealers sell inputs they teach farmers how to use them (Temu et al. 2005). Despite the involvement of many stakeholders in provision of agricultural knowledge to farmers, the level of access to agricultural knowledge among farmers in Tanzania is still low (Lwoga 2010). The agricultural sector in Tanzania is characterised by poor research-extensionfarmers linkage and inaccessibility of agricultural knowledge at farm level (United Republic of Tanzania 2013). Thus, the current study intends to investigate the factors influencing access to agricultural knowledge among smallholder farmers (smallholder farmers in Tanzania own farms ranging in size from $0.2-2$ hectares) in Kilombero district of Tanzania. Specifically, the study identified categories of agricultural knowledge needed by farmers, determined how farmers access agricultural knowledge, and assessed the factors limiting the accessibility of agricultural knowledge among rice farmers in the Kilombero district.

\section{Problem statement}

Despite the importance of the agriculture sector to the economy and the livelihood of the majority of Tanzanians, the sector has been performing poorly (United Republic of Tanzania 2013). In the Kilombero district, limited access to agricultural knowledge has resulted in irrational decisions on agricultural production and related activities thus dwarfing the sector (Benard, Dulle \& Ngalapa 2014; Siyao 2012). At farm level most farmers have inadequate access to and usage of the most important agricultural information services needed for production and post-harvest activities leading to dismal growth of the agricultural sector and prevalence of poverty among households whose livelihoods rely solely on agriculture (Benard et al. 2014; Lwoga 2010; Mtega \& Benard 2013; Shetto 2008; Siyao 2012; United Republic of Tanzania 2011). Inadequate access to agricultural knowledge limits farmers from making rational decisions regarding agricultural production, pre- and post-harvest handling of agricultural produce which in turn affects the level of income from agricultural activities and livelihood of farmers (Lwoga 2010).

\section{Purpose and objectives of the study}

The purpose of this study was to investigate factors influencing access to agricultural knowledge by smallholder rice farmers in the Kilombero district of Tanzania. The specific objectives were to:

- Determine agricultural knowledge needs, acquisition, and usage patterns among rice farmers in the Kilombero district.

- Examine sources of agricultural knowledge used by farmers in the Kilombero district.

- Determine factors limiting access to agricultural knowledge among rice farmers in the Kilombero district.

\section{Literature review}

Farmers have been using skills and expertise in agricultural activities; Lwoga (2010) categorises knowledge used by farmers in agriculture into either indigenous or exogenous knowledge. Indigenous knowledge is the basis for agriculture and natural resource management (Lwoga 2010) because new agricultural knowledge is built from what is known. Indigenous knowledge is local knowledge, it is built from and based on thousands of years of experience and passed from one generation to the next (Ajibade 2003). Indigenous knowledge is predominantly tacit; it is traditional and is passed from a generation to the other through word of mouth (Movarej et al. 2012). The other type of knowledge is exogenous knowledge; this is a broad base of non-traditional 
knowledge that local people draw from their interaction with non-local people and institutions; television, and other media; formal education; and adoption of western scientific thinking, values, and philosophies (Karlsson 1995). To attain the competitive edge in their agricultural undertakings, farmers need both indigenous and exogenous knowledge. These two types of agricultural knowledge are needed for improving farmers' farming skills and helping farmers acquire new techniques for agricultural activities.

\section{Agricultural knowledge needs among farmers}

The agricultural knowledge value chain is made up of those who generate and use knowledge. According to Nonaka et al. (2000), knowledge is created through experience and when people socialise. Once knowledge is created, people acquire it to meet their personal and organisational knowledge needs. However, the various processes constituting agricultural knowledge management involve many actors along the value chain (Lee \& Yang 2000). Each category of actors in the value chain has a task in agricultural knowledge management. However, farmers play a central role in agricultural knowledge management as knowledge created aims to help farmers increase agricultural productivity. Therefore, it is important to enhance access to agricultural knowledge among farmers.

Farmers have different agricultural knowledge needs which are relevant to their day-to-day involvement. Farmers need to know what to grow, when to grow it, how to grow more, how to store and preserve their produce, when to sell, where to sell and at what price to sell, and specific agronomic management skills (Abdon \& Raab 2005). Farmers must know the optimum usage of agricultural inputs for optimal production. The need for agricultural knowledge is increasing because most activities, including agriculture, are being shifted from being labour-based to knowledge-based.

Scholars (Czapiewski, Floriańczyk \& Janc 2010) pointed out that there is a strong link between access to agricultural knowledge and agricultural development. As stated by Dodsworth et al. (2003), agricultural development requires creation and use of new knowledge; it is attained through transforming knowledge into actions. However, knowledge can only be transformed into actions if it is acquired from its sources by those who need it.

\section{Acquisition of agricultural knowledge among farmers}

Acquisition of knowledge involves the importation of substantial amounts of knowledge from internal and external sources of the organisation (Lwoga, Ngulube \& Stilwell 2010). Modes of acquiring indigenous agricultural knowledge may be different from those used in acquiring exogenous knowledge (Yli-Renko, Autio \& Sapienza 2001). Moreover, the way in which tacit knowledge is shared is always different from how explicit knowledge is shared. Tacit knowledge is not easily codifiable and recognisable (Movarej et al. 2012), which ensures that it is shared most effectively through observation and individual experience. Indigenous knowledge is passed from one person to the other through word of mouth (Lwoga 2010) because it is managed by individuals and stored in the minds of individual owners of knowledge. Indigenous knowledge can be documented and repackaged and shared through several channels (Lwoga 2010). Information and communication technologies (ICT), including radio and television sets, internet, computers, and mobile phones, can be used to acquire documented indigenous knowledge.

Explicit knowledge - the know-how that is described in formal language, print, or electronic media, often based on established work processes, uses a people-to-documents approach (Smith 2001). Acquiring this type of knowledge is quite simple; those who need to acquire it must be able to use explicit knowledge carriers and have a reasonable level of literacy. The explicit nature of exogenous knowledge has made its storage and sharing extremely easy, and its popularisation overwhelming (Ocholla 2007). The way in which explicit knowledge is documented makes it easily shared and acquired. Acquiring explicit knowledge needs one to know where knowledge is managed and how it can be acquired.

Exogenous knowledge is acquired from external organisations and communities. People acquire exogenous knowledge through interactions with non-local people and institutions, media, and formal education (Lwoga 2010). People can also acquire exogenous knowledge from people who interact with people coming from the external environment.

Generally, knowledge is acquired to meet knowledge needs expressed by seekers. To enhance easy access of knowledge, codification of tacit knowledge is important. Moreover, having access to both indigenous and exogenous knowledge is important because the two types of knowledge complement each other. For knowledge to be accessed it has to be created or acquired and shared; these processes involve several actors who usually act dependently.

\section{Actors in enhancing access to agricultural knowledge}

An agricultural knowledge value chain is important for enhancing access to agricultural knowledge. The knowledge value chain is simply the application of the value chain model to knowledge development and usage (Powell 2008). The agricultural knowledge value chain involves knowledge acquisition, knowledge innovation, knowledge protection, knowledge integration (intelligence), knowledge dissemination, and knowledge action (Wong 2004). Actors in the agricultural knowledge value chain include those who generate new agricultural knowledge through research and those disseminating the knowledge to those using it for increasing value of the produce or products. Actors in the agricultural sector have to perform all knowledge management processes (creation, storage, sharing, using knowledge) in the agricultural knowledge value chain. A formal agricultural knowledge value chain consists of three functions: research, education and extension, and advisory 
service (Islam 2010; Nemes \& High 2013). Farmers are found at the centre of all agricultural knowledge management activities, because what is being implemented is aimed at increasing agricultural production. However, farmers play a knowledge-creation role just like agricultural research institutions. Farmers generate indigenous knowledge (Lwoga 2010) through experience over a long time and involvement in agricultural activities.

Because of the increasing number of actors in the agricultural knowledge value chain, governments play coordinating roles; thus whatever is being done has a strong positive impact on farmers and other beneficiaries. Kapange (2004) pointed out that governments make sure that agricultural research institutions, universities, extension and advisory services, farmers, and other stakeholders involved in agricultural related activities are effectively involved in agricultural knowledge management processes. Likewise, governments have to invest in knowledge infrastructure in both rural and urban areas; rural knowledge infrastructure is instrumental in boosting the rural development initiatives in villages (Das \& Dutta 2004). Thus, for effective agricultural knowledge management, all the actors must act together to enhance access to and usage of agricultural knowledge.

\section{Research methodology}

In order to investigate the above research objectives, this quantitative study relied on both secondary and primary data. An extensive literature review was undertaken which helped in framing questions for the primary data collection. Quantitative data were collected via semi-structured questionnaires administered face-to-face with rice farmers, community leaders, and agricultural agents in four villages at the Kilombero district of the Morogoro region in Tanzania. According to National Bureau of Statistics (2012), Kilombero district has a population of 407880 people and about $75 \%$ of them are farmers. Among the 305910 farmers 152955 (50\%) of them grow rice and 94\% (143 778 farmers) of them are smallholder farmers (Rural Livelihood Development Company (RLDC) 2009). Because of a lack of a sampling frame, a purposive sample of 120 smallholder rice farmers, community leaders, and agricultural agents was chosen from four villages within Kilombero district. Each village was represented by one agricultural agent who was purposely included in the sample; a village executive secretary because he or she was concerned with day to day activities of the village; and 28 smallholder rice farmers, chosen using a snowball technique, because they were homogeneous and their responses could generalise views of others in the village. This made a total of 30 respondents from each village.

Even though this type of non-probability sampling does not allow representativeness, the sample was easily accessible and organised. Collected data were analysed using the Statistical Package for Social Sciences where both descriptive and inferential statistics were used in data analysis. Tables, figures, and descriptions were used in presenting the study findings.

\section{Findings and discussion}

Analysed data were presented in tables and descriptions as shown. The results are presented as per the objectives of the study.

\section{Demographic characteristics of respondents}

The study involved 53 female and 67 male respondents. Among them, 4 males had informal education, 109 (51 females and 58 males) had primary education, and seven ( 2 females and 5 males) had secondary education and higher. Respondents' ages ranged from 21 to 80 years with the majority of the respondents being between 31 and 40 years of age.

\section{Agricultural knowledge needs, acquisition, and usage among rice farmers in the Kilombero district}

Respondents were asked if they have needed and used knowledge for conducting agricultural activities. Findings indicated that more than $93 \%$ of respondents mentioned that they needed knowledge for performing agricultural activities. Findings indicated that all females involved in the study mentioned that they needed agricultural knowledge for performing agricultural activities (Table 1).

The findings in Table 1 indicated that, regardless of their level of education, all respondents mentioned that they needed knowledge while conducting agricultural activities. Moreover, the need for agricultural knowledge slightly increased with age.

Respondents were further asked about the types of agricultural knowledge they acquired and used. The findings indicated that farmers acquired and used different types of agricultural knowledge. It was found that farmers acquired knowledge related to land preparation, seed selection, rice planting, and fertiliser application. They also mentioned that they needed knowledge related to how to weed their farms, pre-harvest and post-harvest handling, and agricultural marketing.

TABLE 1: Usage of agricultural knowledge in performing agricultural activities.

\begin{tabular}{llcc}
\hline Variable & Category & \multicolumn{2}{c}{ Uses agricultural knowledge } \\
\cline { 3 - 4 } & & $f$ & $\%$ \\
\hline Sex & Female & 53 & 100 \\
\multirow{2}{*}{ Education } & Male & 62 & 93 \\
& Informal & 4 & 100 \\
& Primary & 105 & 96 \\
\multirow{3}{*}{ Age } & Secondary and above & 6 & 86 \\
& $21-30$ & 15 & 94 \\
& $31-40$ & 46 & 92 \\
& $41-50$ & 35 & 100 \\
& $51-60$ & 6 & 100 \\
& $61-70$ & 8 & 100 \\
& $71-80$ & 5 & 100 \\
\hline
\end{tabular}

Source: The data was obtained from a questionnaire $f$, frequency. 
The findings in Table 2 indicated that all famers, regardless of their sex, mentioned to have been acquiring and using agricultural knowledge. Findings indicated that more female respondents mentioned that they have acquired and used agricultural knowledge related to seed selection and rice planting as more than $96 \%$ of female farmers reported to have acquired and used such knowledge (Table 3). Because of rice farming division of labour, female farmers are more involved in some of the rice farming activities than male farmers (Rugumamu 2014). Likely, there are some activities which involve more male farmers than female farmers. Fertiliser application and weeding using herbicides, which involves spraying, is mostly done by male farmers. The findings in Table 2 indicated that $85.1 \%$ of male farmers and $77.4 \%$ female farmers acquired and used knowledge on fertiliser application. Also, $88.1 \%$ of male farmers and $75.5 \%$ of female farmers reported to have acquired and used agricultural knowledge related to using herbicides for weeding. Moreover, male smallholder rice farmers are more involved in pre-harvest or post-harvest handling and marketing of rice $(59.7 \%$ and $58.2 \%$, respectively). This is explained by the fact that in Tanzania husbands in most cases control the household income. These findings align with those of Rugumamu (2014) who also found that more male farmers involve themselves in marketing agricultural produce.

It was found that the level of acquisition of agricultural knowledge was slightly influenced by the level of education.
The findings in Table 2 indicated that, regardless of the level of education, most farmers involved in the study mentioned that they have acquired and used agricultural knowledge related to land preparation, seed selection, and rice sowing. The findings in Table 2 indicated that as a general trend, the level of acquisition of agricultural knowledge among farmers in the Kilombero district decreased with an increase in level of education. This could be explained by the fact that those with higher education might have already accumulated some knowledge needed for performing agricultural activities.

The findings in Table 2 indicated that, regardless of the level of education, more than $88 \%$ of farmers involved in the study acquired knowledge related to land preparation, seed selection, and seed sowing whereas less than $67 \%$ of farmers involved in the study mentioned that they have acquired knowledge on pre- and post-harvest handling procedures (Table 2). Likely, the need for knowledge related to rice markets increased with an increase in age. It was found that approximately $68 \%$ respondents between 31 and 50 years mentioned that they have acquired and used knowledge related to rice marketing; however, the need and the level of acquisition of knowledge related to agricultural marketing increased with an increase in age (Table 2).

Generally, almost all farmers involved in the study needed and acquired agricultural knowledge related to different agricultural activities. They needed knowledge for adding

TABLE 2: Agricultural knowledge acquired by rice farmers.

\begin{tabular}{|c|c|c|c|c|c|c|c|c|}
\hline Variable & Category & $\begin{array}{l}\text { Knowledge on } \\
\text { land preparation } \\
(\%)\end{array}$ & $\begin{array}{l}\text { Knowledge on } \\
\text { seed selection } \\
(\%)\end{array}$ & $\begin{array}{l}\text { Knowledge on } \\
\text { rice planting } \\
(\%)\end{array}$ & $\begin{array}{l}\text { Knowledge } \\
\text { on fertiliser } \\
\text { application } \\
(\%) \\
\end{array}$ & $\begin{array}{l}\text { Knowledge on } \\
\text { how to weed } \\
(\%)\end{array}$ & $\begin{array}{l}\text { Knowledge on } \\
\text { pre-harvest and } \\
\text { post-harvest } \\
\text { handling }(\%)\end{array}$ & $\begin{array}{l}\text { Knowledge on } \\
\text { agricultural } \\
\text { marketing } \\
(\%)\end{array}$ \\
\hline \multirow[t]{2}{*}{ Sex } & Female & $47(88.7)$ & $53(100.0)$ & $51(96.2)$ & $41(77.4)$ & $40(75.5)$ & $27(50.9)$ & $26(49.0)$ \\
\hline & Male & $61(91.0)$ & $62(92.5)$ & $62(92.5)$ & $57(85.1)$ & $59(88.1)$ & $40(59.7)$ & $39(58.2)$ \\
\hline \multirow[t]{3}{*}{ Education } & Informal & $4(100.0)$ & $4(100.0)$ & $4(100.0)$ & $4(100.0)$ & $0(0.0)$ & $4(100.0)$ & $0(0.0)$ \\
\hline & Primary & $98(89.9)$ & $105(96.3)$ & $103(94.5)$ & $88(80.7)$ & $20(18.3)$ & $60(55.0)$ & $72(66.1)$ \\
\hline & Secondary and above & $6(85.7)$ & $6(85.7)$ & $6(85.7)$ & $6(85.7)$ & $1(14.3)$ & $3(42.9)$ & $3(42.9)$ \\
\hline \multirow[t]{6}{*}{ Age } & $21-30$ & $15(93.8)$ & $15(93.8)$ & $15(93.8)$ & $10(62.5)$ & $9(56.3)$ & $6(37.5)$ & $4(25.0)$ \\
\hline & $31-40$ & $44(88.0)$ & $46(92.0)$ & $44(88.0)$ & $42(84.0)$ & $42(84.0)$ & $26(52.0)$ & $34(68.0)$ \\
\hline & $41-50$ & $31(88.6)$ & $35(100.0)$ & 35 (100.0) & 29 (82.9) & 29 (82.9) & $23(65.7)$ & $23(65.7)$ \\
\hline & $51-60$ & $6(100.00)$ & $6(100.0)$ & $6(100.0)$ & $4(66.7)$ & $6(100.0)$ & $4(66.7)$ & $4(66.7)$ \\
\hline & $61-70$ & $8(100.0)$ & $8(100.0)$ & $8(100.0)$ & $8(100.0)$ & $8(100.0)$ & $4(50.0)$ & $6(75.0)$ \\
\hline & $71-80$ & $4(80.0)$ & $5(100.0)$ & $5(100.0)$ & $5(100.0)$ & $5(100.0)$ & $4(80.0)$ & $4(80.0)$ \\
\hline
\end{tabular}

Source: The data was obtained from a questionnaire

TABLE 3: Preference of sources of agricultural knowledge by demographic characteristics.

\begin{tabular}{|c|c|c|c|c|c|c|c|c|c|c|}
\hline Variables & Category & $\begin{array}{l}\text { Village } \\
\text { leader } \\
(\%)\end{array}$ & $\begin{array}{l}\text { Demons- } \\
\text { tration plot } \\
(\%)\end{array}$ & $\begin{array}{l}\text { Mobile } \\
\text { phones } \\
(\%)\end{array}$ & $\begin{array}{l}\text { Farmers' } \\
\text { associations } \\
(\%)\end{array}$ & $\begin{array}{l}\text { TV } \\
(\%)\end{array}$ & $\begin{array}{l}\text { Print } \\
\text { resources } \\
(\%)\end{array}$ & $\begin{array}{l}\text { Radio } \\
(\%)\end{array}$ & $\begin{array}{l}\text { Fellow } \\
\text { farmers } \\
(\%)\end{array}$ & $\begin{array}{l}\text { Agricultural } \\
\text { extension agent } \\
(\%)\end{array}$ \\
\hline \multirow[t]{2}{*}{ Sex } & Female & $16(30.2)$ & $35(66.0)$ & $16(30.2)$ & $17(32.1)$ & $3(5.7)$ & $17(32.1)$ & $20(37.7)$ & 10 (18.9) & $35(66.0)$ \\
\hline & Male & $25(37.3)$ & $49(73,1)$ & $32(47.8)$ & $35(52.2)$ & $16(23.9)$ & $29(43.3)$ & $33(49.3)$ & $21(31.3)$ & $35(52.2)$ \\
\hline \multirow[t]{3}{*}{ Education } & Informal & $0(0.0)$ & $0(0.0)$ & $0(0.0)$ & $0(0.0)$ & $0(0.0)$ & $0(0.0)$ & $0(0.0)$ & $0(0.0)$ & $4(100.0)$ \\
\hline & Primary & $41(37.6)$ & $78(71.6)$ & 45 (41.3) & $46(42.2)$ & $19(17.4)$ & $40(36.7)$ & $50(45.9)$ & $28(25.7)$ & $63(57.8)$ \\
\hline & Secondary and above & $0(0.0)$ & $6(85.7)$ & $3(42.9)$ & $6(85.7)$ & $0(0.0)$ & $6(85.7)$ & $3(42.9)$ & $3(42.9)$ & $3(42.9)$ \\
\hline & $31-40$ & $16(32.0)$ & $37(74.0)$ & $25(50.0)$ & $27(54.0)$ & $6(12.0)$ & $23(46.0)$ & $22(44.0)$ & $13(26.0)$ & $33(66.0)$ \\
\hline & $41-50$ & 15 (42.9) & $24(68.6)$ & $10(28.6)$ & $17(48.6)$ & $6(17.1)$ & $10(28.6)$ & $10(28.6)$ & $8(22.9)$ & $21(60.0)$ \\
\hline & $51-60$ & $2(33.3)$ & $4(66.7)$ & $3(50.0)$ & $1(16.7)$ & $0(0.0)$ & $3(50.0)$ & $3(50.0)$ & $1(16.7)$ & $6(100.0)$ \\
\hline & $61-70$ & $0(0.0)$ & $4(50.0)$ & $2(25.0)$ & $2(25.0)$ & $4(50.0)$ & $4(50.0)$ & $6(75.0)$ & $0(0.0)$ & $0(0.0)$ \\
\hline & $71-80$ & $1(20.0)$ & $5(100.0)$ & $5(100.0)$ & $3(60.0)$ & $3(60.0)$ & $3(60.0)$ & $3(60.0)$ & $5(100.0)$ & $5(100.0)$ \\
\hline
\end{tabular}

Source: The data was obtained from a questionnaire 
value to agricultural undertakings they are involved in. Most farmers appreciated the fact that the usage of agricultural knowledge increased agricultural production and income from agriculture, which in turn increased their livelihood.

\section{Sources of agricultural knowledge used by farmers in the Kilombero district}

Farmers involved in the study were asked about the sources from which they acquired agricultural knowledge. It was found that farmers acquired agricultural knowledge from village leaders, demonstration plots, mobile phones, farmers' associations, TV sets, print resources, radio sets, fellow farmers, and agricultural extension agents (Table 3). Among the knowledge sources mentioned by more respondents were demonstration plots; findings in Table 3 indicate that more respondents preferred this source of agricultural knowledge because farmers had opportunities to observe and adopted what has been practiced to their farms. Moreover, more male farmers had more access to these sources of agricultural knowledge because they spent their leisure time after farm activities accessing different knowledge sources, whereas females spent such time for preparing meals.

The findings in Table 2 indicated that more male than female farmers acquired agricultural knowledge for their agricultural activities; likewise, the findings in Table 3 indicated that more male farmers used agricultural knowledge sources for accessing agricultural knowledge. The findings in Table 3 showed that more male farmers $(73.1 \%)$ reported to use demonstration plots as a source of agricultural knowledge.

Preference of agricultural knowledge was influenced by farmers' level of education. Findings indicated that all farmers with informal education mentioned to have been using agricultural extension agents as their source of agricultural knowledge; most of those with primary level of education (71.6\%) mentioned to have been using demonstration plots. Those with secondary levels of education and higher $(85.7 \%)$ mentioned that they preferred to use demonstration plots, farmers' associations, and print resources as sources of agricultural knowledge (Table 3). With respect to ICT-based sources, more respondents reported to have been using radio sets $(45.9 \%)$, followed by mobile phones. The findings in Table 3 indicated that the level of usage of these ICTs as sources of agricultural knowledge increased with an increase in the level of education. This shows that literacy plays an important role in the choice of agricultural knowledge sources. The same trend applies to the usage of print resources as sources of agricultural knowledge as none of those with informal education used print resources, whereas $85.7 \%$ of those with a secondary level of education and higher used print resources for accessing agricultural knowledge.

Findings in Table 3 indicate that all of the oldest farmers (71-80 years of age) involved in the study said that they have used demonstration plots, mobile phones, fellow farmers, and agricultural extension agents for accessing agricultural
TABLE 4: Sharing of agricultural knowledge by demographic characteristics.

\begin{tabular}{lll}
\hline Variable & Category & $\boldsymbol{f ( \% )}$ \\
\hline Sex & Female & $37(69.8)$ \\
Education & Male & $51(76.1)$ \\
& Informal & $0(0.0)$ \\
& Primary & $82(75.2)$ \\
Age & Secondary & $6(85.7)$ \\
& $21-30$ & $8(50.0)$ \\
& $31-40$ & $39(78.0)$ \\
& $41-50$ & $26(74.3)$ \\
& $51-60$ & $4(66.7)$ \\
& $61-70$ & $8(100.0)$ \\
$71-80$ & $3(60.0)$ \\
\hline
\end{tabular}

Source: The data was obtained from a questionnaire

knowledge. Findings indicate further that $60 \%$ of respondents within the same age category mentioned that they used farmers' associations, TV sets, print resources, and radio sets for accessing agricultural knowledge. Regardless of age, demonstration plots and agricultural extension agents were the most used sources of agricultural knowledge. This is explained by the fact that these sources were close to where farmers live. Moreover, regardless of age, TV sets were the least used sources of agricultural knowledge among farmers involved in the study. This is explained by the limited TV infrastructure in most rural areas.

Farmers involved in the study were asked if they shared acquired knowledge. It was found that farmers involved in the study used to share knowledge among themselves. The findings indicated that more male farmers $(76.1 \%)$ shared acquired agricultural knowledge than female farmers $(69.8 \%)$. Moreover, it can be seen from Table 4 that the level of sharing agricultural knowledge increases with the level of education; none of those with informal education said that they have shared acquired knowledge whereas more than $75 \%$ of those with a primary level of education and higher said that they have shared acquired agricultural knowledge.

The findings indicated that sharing agricultural knowledge was the lowest among the youngest farmers involved in the study as only $50 \%$ of them said that they have shared agricultural knowledge. Between the two groups with many respondents, it was found that $78 \%$ of those between 31 and 40 years of age and $74.3 \%$ of those between 41 and 50 years of age said that they have shared acquired agricultural knowledge. Lwoga (2010) mentioned that sharing agricultural knowledge among rural farmers is important because of the limited number of agricultural knowledge sources.

\section{Factors limiting access to agricultural knowledge among rice farmers in the Kilombero district}

The study aimed at identifying factors that influence accessibility of agricultural knowledge among farmers. Farmers identified a number of factors that limited access to agricultural knowledge. Table 5 shows that $58 \%$ said that they did not get agricultural trainings. Findings indicate that more males included in the study found this to be hindering access to agricultural knowledge (Table 5). 
TABLE 5: Factors influencing access to agricultural knowledge.

\begin{tabular}{lccc}
\hline Factors & \multicolumn{3}{c}{$f$} \\
\cline { 2 - 4 } & $\begin{array}{c}\text { Male } \\
(\mathbf{\%})\end{array}$ & $\begin{array}{c}\text { Female } \\
(\mathbf{\%})\end{array}$ & $\begin{array}{c}\text { Total } \\
(\mathbf{\%})\end{array}$ \\
\hline Few farmers have been given agricultural training & $48(72)$ & $22(42)$ & $70(58)$ \\
Few demonstration plots in the village & $44(66)$ & $43(81)$ & $87(73)$ \\
Unaffordable information services & $34(51)$ & $48(91)$ & $82(68)$ \\
No exchange visits among farmers & $27(40)$ & $28(53)$ & $55(46)$ \\
Demonstration plots are not established on time & $42(63)$ & $50(94)$ & $92(77)$ \\
Limited agricultural campaigns & $39(58)$ & $36(68)$ & $75(63)$ \\
Information services not delivered on time & $52(78)$ & $37(70)$ & $89(74)$ \\
\hline Few agricultural extension agents & $59(88)$ & $43(81)$ & $102(85)$ \\
Few agro-dealers & $25(37)$ & $6(11)$ & $31(26)$ \\
Limited ICT infrastructure & $65(97)$ & $52(98)$ & $117(98)$ \\
Illiteracy among farmers & $42(63)$ & $28(53)$ & $70(58)$ \\
\hline
\end{tabular}

Source: The data was obtained from a questionnaire

$\mathrm{ICT}$, information and communication technologies.

The findings in Table 5 further indicated that other factors limiting access to agricultural knowledge among rice farmers in the Kilombero district included: limited exchange visits among farmers (46\%); few demonstration plots established in the village $(73 \%)$; most demonstration plots found in villages have not been established on time (77\%); and the high cost of some of the information services (68\%). Despite being mentioned by most respondents to influence access to agricultural knowledge, it was found that more females included in the study mentioned those factors to limit access to agricultural knowledge.

Other factors included a limited number of agricultural campaigns (63\%); a delay in most information services (74\%); a limited number of agricultural extension agents (85\%); few agro-dealers (26\%); illiteracy among farmers (58\%); and limited ICT infrastructure (98\%). As indicated in Table 5, more male respondents included in the study mentioned limited agricultural campaigns; delay in most information services; limited number of agricultural extension agents and agrodealers; and high illiteracy level hindered access to agricultural knowledge among farmers. Table 5 shows further that both male and female respondents believed that limited ICT infrastructure hindered access to agricultural knowledge.

From Table 3, demonstration plots and agricultural extension agents were mentioned as the most used sources of agricultural knowledge. Despite the fact that they were really useful and that most farmers depended on them, such sources were not adequate. Only a few demonstration plots were established and most of them were not established on time. If enough demonstration plots were established, and those few available could be established on time then their impact on adoption could be higher than it was. According to Shetto and Owenya (2007), most demonstration plots are established by private agricultural service providers including non-governmental organisations. Despite being helpful, private service providers do not provide service in all rural areas or to all institutes and farmers. ICTs could have been used to break the gap; however, findings from this study and other studies (Lwoga 2010; Mtega 2012; Sife, Kiondo \& Lyimo-Macha 2010; Shetto 2008) showed that most rural areas have very limited ICT infrastructure.
It could be found that some of the factors limiting access to agricultural knowledge are caused by individual farmers, while others are institutional. Factors relating to individual farmers could include illiteracy and low income, which would limit some farmers from accessing agricultural knowledge. The rest of the factors are institutional factors and in one way or the other, they may be solved through a strong public-private partnership as the public or private sector alone cannot eradicate them. Thus, access to agricultural knowledge depends on the involvement of farmers, and the private and the public sector.

\section{Conclusion and recommendations}

The study investigated the factors influencing access to agricultural knowledge among smallholder farmers in the Kilombero district of Tanzania. Key findings indicated that all farmers have been accessing and using agricultural knowledge in undertaking agricultural activities. It was found that the level of acquisition of agricultural knowledge increased with an increase in age and that more farmers needed agricultural knowledge on land preparation, seed selection, and rice planting. It was also found that other farmers needed knowledge on agricultural markets and that demonstration plots and agricultural extension agents were the agricultural knowledge sources consulted by most farmers. Despite the need for agricultural knowledge among farmers in the district, a limited number of demonstration plots, late delivery of information services, a limited number of agricultural extension agents, and limited ICT infrastructure hindered access to agricultural knowledge among rice farmers in Kilombero. A strong public-private partnership is needed to enhance access to agricultural knowledge in rural areas. The government should set up policies and strategies that motivate private sector investment and involvement in the provision of agricultural information in rural areas. The private sector should extend their agriculture-related activities to rural areas so that more people can have access to agricultural knowledge.

\section{Acknowledgements Competing interests}

The authors declare that they have no financial or personal relationships which may have inappropriately influenced them in writing this article.

\section{Authors' contributions}

M.N. was the project supervisor and L.D. was the cosupervisor. W.P.M. conceptualised the work, and collected and interpreted the data.

\section{References}

Abdon, B. \& Raab, R., 2005, 'Knowledge sharing and distance learning for sustainable agriculture in the Asia-Pacific region: The role of the Internet', Plant Production Science 8(3), 298-307. http://dx.doi.org/10.1626/pps.8.298

Ajibade, L.T., 2003, 'Knowing the unknown through the known: The case for indigenous knowledge in sustainable development', viewed 14 January 2015, from http:// afrrevjo.net/journals/multidiscipline/Vol_2_num_2_art_14_Ajibade.pdf 
Benard, R., Dulle, F. \& Ngalapa, H., 2014, 'Assessment of information needs of rice farmers in Tanzania; A case study of Kilombero District, Morogoro', Library Philosophy and Practice (e-journal), 1-34, viewed 30 January 2015, from Philosophy and Practice (e-journal), 1-34, viewed 30 January 2015, from
http://digitalcommons.unl.edu/cgi/viewcontent.cgi?article=2666\&context=libphi Iprac

Bowker, G.C., Baker, K.S., Millerand, F. \& Ribes, D., 2010, 'Towards information infrastructure studies: Ways of knowing in a networked environment', in J.D. Hunsinger, M. Allen \& L. Klastrup (eds.), International handbook of internet Hunsinger, M. Allen \& L. Kearch, Springer, New York.
rese

Czapiewski, K., Floriańczyk, Z. \& Janc, K., 2010, 'Agricultural knowledge and rural economy - analysis on micro and macro scales', viewed 14 January 2015, from http://eprints.rclis.org/bitstream/10760/7210/1/Das_Dutta_XXI_IASLIC Seminar_2004.pdf

Das, A.K. \& Dutta, C., 2004, 'Strengthening Rural Information Infrastructure through E-Choupals', viewed 25 January 2015, from http://eprints.rclis.org/7210/1/Das Dutta_XXI_IASLIC Seminar_2004.pdf

Dodsworth, E., Smith, S., Biswas-Benbow, I., Lloyd-Laney, M., Young, J. \& Winder, D. 2003, 'New DFID research strategy communications theme-final report', viewed 10 February 2015, from http://www.cimrc.info/pdf/news/CommsStrategy.pdf

Eenhoorn, H. \& Becx, G., 2009, 'Constrain constraints: A study into real and perceived constraints and opportunities for the development of smallholder farmers in SubSaharan Africa', viewed 12 January 2015, from http://www.resilience-foundation. $\mathrm{nl} /$ docs/eenhoornandbecx2009.pdf

Frické, M., 2009, 'The knowledge pyramid: A critique of the DIKW hierarchy', Journal of Informationscience 35(2),131-142.http://dx.doi.org/10.1177/0165551508094050

Islam, F., 2010, 'Institutionalization of agricultural knowledge management system for digital marginalized brural farming community', viewed 12 January 2015, from https://hal.archives-ouvertes.fr/hal-00516458/document

Kagan, A., 1999, 'The growing gap between the information rich and the information poor both within countries and between countries: A composite policy paper', poor both within countries and between countries: A composite policy paper
IFLA Journal 26(1), 28-33. http://dx.doi.org/10.1177/034003520002600105

Kapange, B., 2004, 'ICTs and National Agricultural Research Systems: The case of Tanzania', viewed 24 January 2015, from http://www.tzonline.org/pdf/ ictsandnationalagriculturalresearchsystems.pdf

Karlsson, J., 1995, 'Methods of information provision to rural communities in South Africa', in E. Johansson (ed.), Seminar on information provision to rural communities in Africa: Proceedings of the seminar, pp. 47-57, Gaborone.

Lee, C.C. \& Yang, J., 2000, 'Knowledge-value chain', Journal of Management Development 19, 783-793. http://dx.doi.org/10.1108/02621710010378228

Lema, M.A. \& Majule, A.E., 2009, 'Impacts of climate change, variability and adaptation strategies on agriculture in semi-arid areas of Tanzania: The case of Manyoni District in Singida Region, Tanzania', African Journal of Environmental Science and Technology 3(8), 206-218.

Lema, N.M. \& Kapange, B.W., 2006, 'Farmers' organizations and agricultural innovation in Tanzania: The sector policy for real farmer empowerment', viewed 25 January 2015, from http://www.kit.nl/sed/wp-content/uploads/publications/912_Case $\% 20$ 2015, from http://www.
Study\%20Tanzania.pdf

Lobell, D.B. \& Gourdji, S.M., 2012, 'The influence of climate change on global crop productivity', Plant Physiology 160(4), 1686-1697.

Lwoga, E.T., 2010, 'Bridging the agricultural knowledge and information divide: The case of selected telecenters and rural radio in Tanzania', Electronic Journal on Information Systems in Developing Countries 43(6), 1-14.

Lwoga, E.T., 2011, 'Knowledge management approaches in managing agricultural indigenous and exogenous knowledge in Tanzania', Journal of Documentation 67(3), 113-122.

Lwoga, E.T., Ngulube, P. \& Stilwell, C., 2010, 'Managing indigenous knowledge fo sustainable agricultural development in developing countries: Knowledg management approaches in the social context', The International Information \& Library Review 42(3), 174-175. http://dx.doi.org/10.1080/10572317.2010.107 62862

Lwoga, E.T., Ngulube, P. \& Stilwell, C., 2011, 'Information Needs and Information Seeking Behaviour of Small-Scale Farmers in Tanzania', Innovation: Journal of Appropriate Librarianship and Information Work in Southern Africa 40 (2010).

Movarej, M., Hashemi, S.M.K., Hosseini, S.M. \& Rezvanfar, A., 2012, 'Facilitating sustainable agriculture: Integrating indigenous knowledge in current agricultural knowledge and information systems', Cercetări Agronomice în Moldova XLV(1) viewed 14 January 2015, from http://www.uaiasi.ro/CERCET_AGROMOLD/CA1 12-10.pdf
Mtega, W.P., 2012, 'Access to and usage of information among rural communities: A case study of Kilosa District Morogoro Region in Tanzania', Partnership: The Canadian Journal of Library and Information Practice and Research 7(1). http://dx.doi.org/10.21083/partnership.v7i1.1646

Mtega, W.P. \& Benard, R., 2013, 'The state of rural information and communication services in Tanzania: A meta-analysis', International Journal of Information and Communication Technology Research 3(2), 64-73.

National Bureau of Statistics, 2012, 'Population and housing census: Morogoro region population', viewed 15 January 2015, from http://www.nbs.go.tz/sensa/popu2.php

Nazari, M.R., Bin, H.J. \& Hassan, S., 2011, 'The role of television in the enhancement of farmers' agricultural knowledge', African Journal of Agricultural Research 6(4), 931-936.

Nemes, G. \& High, C., 2013, 'Old institutions, new challenges: The agricultural knowledge system in Hungary', Studies in Agricultural Economics 115(2), 76-84. http://dx.doi.org/10.7896/j.1303

Nonaka, I., Toyama, R. \& Konno, N. 2000, 'SECl, ba and leadership: A unified model of dynamic knowledge creation', Long Range Planning 33, 5-34.

Ocholla, D., 2007, 'Marginalized knowledge: An agenda for indigenous knowledge development and integration with other forms of knowledge', International Review of Information Ethics, 7, 237-243.

Powell, T., 2008, 'The knowledge value chain (KVC): How to fix it when it breaks', viewed 20 October 2015, from http://www.knowledgeagency.com/sites/ knowledgeagency.com/files/KVC\%2OHow\%20to\%20Fix\%20lt\%20080501.pdf

Rugumamu, C.P., 2014, 'Empowering smallholder rice farmers in Tanzania to increase productivity for promoting food security in eastern and southern Africa', Agriculture \& Food Security 3(7), viewed 20 January 2015, from http://www. agricultureandfoodsecurity.com/content/3/1/7

Rural Livelihood Development Company (RLDP), 2009, 'Improving rice profitability through increased productivity and better marketing focusing on Tanzania's central Corridor', viewed 20 October 2015, from http://www.rldp.org/downloads/ rice_strategy.pdf

Rutatora, D.F. \& Mattee, A.Z., 2001, 'Major agricultural extension providers in Tanzania', African Study Monographs 22(4), 55-173.

Shetto, M.C., 2008, 'Assessment of agricultural information needs in African Caribbean and Pacific (ACP) States Eastern Africa Country study: Tanzania', Final Report, viewed 10 January 2015, from http://www.researchintouse.com/ resources/ext/cta08tz-agriinfoneed-rpt.pdf

Shetto, R., \& Owenya, M., 2007, Conservation agriculture as practiced in Tanzania: three case studies, African Conservation Tillage Network, Nairobi, viewed n.d. from http://www.fao.org/ag/ca/doc/tanzania_casestudy.pdf

Sife, A.S., Kiondo, E. \& Lyimo-Macha, J.G., 2010, 'Contribution of mobile phones to rural livelihoods and poverty reduction in Morogoro region, Tanzania', Electronic Journal of Information Systems in Developing Countries 42(3), 1-15.

Siyao, P.O., 2012, 'Barriers in accessing agricultural information in Tanzania with a Gender perspective: The case study of small-scale sugar cane growers in Kilombero district', Electronic Journal of Information Systems in Developing Countries 51(6), 1-19.

Smith, E.A., 2001, 'The role of tacit and explicit knowledge in the workplace' Journal of Knowledge Management 5(4), 311-321. http://dx.doi.org/ 10.1108/13673270110411733

Temu, A.E., Nyange, D., Mattee, A.Z. \& Kashasha, L.K., 2005, 'Assessing rural services, infrastructure and their impact on agricultural production, marketing and food security infrastructure and their impact on agricultural production, marketing and food security AssessingRuralServiceslandInfrastructureonAgriculturalProduction_Tanzania.pdf

Tilman, D., Cassman, K.G., Matson, P.A., Naylor, R. \& Polasky, S., 2002, 'Agricultural sustainability and intensive production practices', Nature 418, 671-677. http:// sustainability and intensive productiong/10.1038/nature01014
dx.doi.org

United Republic of Tanzania, 2011, Tanzania Agriculture and Food Security Investment Plan 2011/12 to 2020/21, Government Printers, Dar es Salaam.

United Republic of Tanzania, 2013, National agriculture policy, Government Printers, Dar es Salaam, Tanzania.

Wong, H.K., 2004, 'Knowledge value chain: Implementation of new product development system in a winery', The Electronic Journal of Knowledge Management 2(1), 77-90.

Yli-Renko, H., Autio, E. \& Sapienza, H.J., 2001, 'Social capital, knowledge acquisition, and knowledge exploitation in young technology-based firms', Strategic Management Journal 22, 587-613. http://dx.doi.org/10.1002/smj.183 